\title{
HIGHER EDUCATION AS PART OF THE MODERNIZATION OF CONTEMPORARY POLAND
}

\begin{abstract}
The aim of the article is to analyze the social problem of mass education within higher education. This process was particularly noticeable in the late 1990s and in the early 2000s. The phenomenon accompanying the massification of higher education was the creation of private universities. This research describes two studies utilizing two study modes - full-time and part-time (extramural). The analysis of the research problem was made on the basis of statistical data from sources of official statistics as well as reports, analyses, and scientific publications. The findings from this process included a significant increase in the number of people who started part-time studies at public or private universities. In the years 1990-2017, the number of universities increased from 162 to 390, and their students from 390000 students to 1292,000 students; the number of graduates increased from 56,000 to 387,000 . One of the most important effects of the mass education process of higher education was a significant increase in the level of education of the population.
\end{abstract}

Keywords: higher education, massification of higher education, modernization, universities.

\section{INTRODUCTION}

From the perspective of a long-lasting process, universities were the centres which gave birth to new ideas, theoretical concepts and new technological solutions. Higher education institutions were a forge of social elites and intellectual societies. A historical look at the importance of universities in Europe takes us back to the early Middle Ages, where universitas meant institutionalized community of knowledge and scientific research, where values, standards and community of concepts created a spiritual frame of then contemporary Europe. The only language that was used by science in those days- Latin, created a kind of communication community and a platform for cooperation and understanding and brought closer distant academic centres of Europe (Ciechanowska, 2012). For many centuries the opportunity to continue their education at a higher level was reserved only for the few. Property, status and social hierarchy-based qualifications prevented many individuals and social groups from taking advantage of education. This trend was apparent practically throughout the entire twentieth century. In fact, throughout the period of People's Republic of Poland higher education had the elitist status. This was a consequence of a low value of education in society, especially in groups situated at the lower levels of the social ladder, even in spite of numerous ideological attempts to change it, like the introduction of preferential points for social background. Obviously, these attempts had to be ineffective as

\footnotetext{
${ }^{1}$ Hubert Kotarski, PhD, Institute of Sociology, University of Rzeszów; e-mail: kotarski@ur.edu.pl.
} ORCID: 0000-0002-5370-7099. 
the accessibility of higher education for rural and workers' youth was largely limited, primarily by institutional factors, including the barriers at the earlier educational stages, a relatively small number of universities, as well as socio-cultural conditioning (Wasielewski, 2015).

After the end of World War II, higher education in the world experienced a number of significant changes, gradually shifting from an elitist model of higher education, which is characterized by a small number of independently existing institutions and a focus on educating a small group of young people from the upper classes, to the model of universal education, increasingly oriented to the needs of the labour market (Dybaś, DziemianowiczBąk, Krawczyk-Radwan, Walczak, 2012). In Poland, the process started at the beginning of the nineties of the twentieth century. This delay was associated with social and economic changes that resulted from the introduction of a free market economy.

\section{HIGHER EDUCATION AND MODERNIZATION}

The term "modernization" is closely linked with the concept of development and in this aspect it means transformation, or continuous transformation. This term is qualitative and positive. It concerns the transformation of both economy and society, which allows for a marked improvement in their functioning. In modern terms, the "macro" concept means further advancement of the economic structure, its increased modernity and elimination of institutional cultural and technical barriers inhibiting social entrepreneurship (Gudowski, 2010). Today it has been accepted, among others in social sciences, to use special indicators to measure the level of modernization of countries or societies. These indicators can be recognized at different levels:

1. In economics - the detailed measures of modernization may be, for example, the GDP per capita measured in a given period of time or the Human Development Index (HDI).

2. In demography - there specific indicators may be: infant mortality rate per 1,000 live births for a given period of time or, life expectancy of a person born in a given year expressed in years.

3. In economy - the indicator in this area may be the structure of sectors (branches) concerned.

4. In the quality of life - the detailed measures of modernization can be, for example: the ratio of life-satisfaction or the Gini coefficient (of social inequalities).

5. In education - in this area the indicators can be, for example, the structure of residents' education, the system of higher education or the number of university graduates completing their higher education in a given year.

Changes in higher education and including them in the process of modernization were associated with the change of knowledge availability paradigm. The changes that took place in higher education, were both quantitative - a significantly increased number of studying persons and qualitative - a radical redefinition of the role of higher education. In the previously dominant elitist model the university education was reserved for a small group of students from privileged social classes, allowing for a few exceptions. These persons had substantial resources of social capital and cultural capital, which they received from parents as a kind of inheritance. Knowledge which was imparted during studies based on such a model did not necessarily have to be useful to perform a specific job or profession, which does not imply, however, that it wasn't highly functional - after all, the fact of having it 
confirmed and legitimized social position occupied by its holder. It was only with the change in perceiving the mission of higher education, and in particular with the need resulting from a new economic and social context to appreciate the role that education can have on the labour market and for the economy, that the gradual opening up of universities onto a wider group of young people from diverse social backgrounds took place (Dybaś, Dziemianowicz-Bąk, Krawczyk-Radwan, Walczak, 2012). This process was also visible in Poland, where we can venture to say that in the last two decades Polish higher education was forced to seek a state of relative balance between the arising contradictions. These being, on the one hand, the need to continue the current policy of higher education development, referring to the diagrams and models developed by tradition, on the other hand, the need to address modernization challenges imposed by the risk society and knowledge society (Karczmarczuk, 2009).

So far the main driver of educational changes were dynamically developing production technologies. In the twenty-first century they give way to the education which grows to be a decisive component of the development of 'new economy'. Education striving for the development of reason by enlightenment standards becomes insufficient. The traditional model of instructing education, must be put to rest, and replaced with a model of forming education, developing students' personality in terms of their intellect, affective and psychomotor learning (Denek, 1998). It became a widespread belief that living in the risk society, as defined by Ulrich Beck (Beck, 2002), young people find in the increasingly better education a specific escape from uncertainty of their professional and social future. The drive toward higher education may reduce the risk of social marginalization.

\section{MASSIFICATION OF HIGHER EDUCATION}

The transformations in the higher education sector determine three neo-liberal institutional arrangements. The first of these is associated with neo-liberal economic reforms, initiated two decades ago, which aimed primarily at significant reduction in the state's role in the economy and in other spheres of social life. In the higher education sector this limitation of the role of the state was made possible by the amendment of the Law on Higher Education Act of 12 September 1990 (Journal of Laws No. 65 item 385, as amended). It opened the way for a free and autonomous development of higher education by restoring decision-making powers to the rectors and university senate. It rejected the past strategy of funding higher education entirely from public funds, introduced a very broad autonomy for public universities, created conditions for the creation of private universities, which in turn led to the marketisation and "commodification" of teaching and research processes. Another institutional solution became the Bologna Process adopted by the Member States of the European Union in 1999. They agreed on the general principles of organizing education, the so-called European Higher Education Area, which were to lead consequently to profound transformations in the higher education systems in all countries of the European Union. In practice, this meant opening the higher education sector to competition, privatization and marketisation (Karczmarczuk, 2010). The third institutional solution that influenced the transformation of the higher education sector was Poland's accession to the European Union, which contributed, among other things, to the increase in mobility of students and teaching staff and participation in programs financed from the EU funds (e.g. Erasmus and Erasmus Plus), more application chances due to the European Union financial support, or more funding for human resources (e.g. Human Capital 
Operational Programme) and placing greater emphasis on increasing the access and dissemination of continuing education.

Two fundamental changes that took place in the Polish higher education in the 90s of the twentieth century largely contributed to the transition from the elitist to universal higher education. The first of these was the development of non-public higher education, which resulted in the most developed non-public education system in Europe. The second change, which was made possible by the Higher Education Act of 1990, authorizing the introduction of fees for some educational services, helped develop the system of paid evening studies, part-time and postgraduate studies in state universities. Popularisation of Polish higher education has some special characteristics. Firstly, over the twenty years of political transformation there increased abruptly the number of students, resulting in the Europe's highest level of popularity of tertiary education. Second, the spread of higher education decreased the value of university degrees in the labour market. On the one hand, in the late 90 s of the twentieth century the labour market started to welcome the first graduates enrolled under the "educational boom", on the other hand, a university degree gradually ceased to be not so much a guarantee of well-paid job, as a protection against unemployment. Thirdly, the "educational boom" caused an increase in the number of people with higher education in the total population of economically active Poles between 19 and 64 years old, which means that the popularisation of higher education directly resulted in increased competition in the labour market among people with higher education. Fourth, since the liberalization of the Higher Education Act in 1990 the number of higher education institutions has increased. The higher education institutional order has started to undergo a continuous change. Free-market rules in higher education (especially non-public universities) caused that the universities' names began to evolve, higher education institutions began to fall, merge, and even be taken over by stronger institutions. Non-public universities have become smaller, less institutionally stable, and therefore more susceptible to demographic fluctuations. In addition to the sector of newly-created non-public higher education institutions there have also appeared new public universities - mostly State Higher Vocational Schools (PWSZ), created especially in the towns that lost their status of regional centres as a result of the administrative reform in 1999, and which clearly lacked public higher education institutions. Popularisation of higher education was therefore accompanied by strong institutional fragmentation and instability. Fifth, the transition from the elitist to universal model of higher education has changed the nature of higher education. Popularisation of education caused a revolution in the understanding of the concept of higher education, leading to it being more practical or relevant for the labour market. The issue of employability of graduates, providing them with the market-relevant qualifications became part of the educational policy. Popularisation of higher education has fundamentally changed educational goals, which led to a reformulation of its contents. In addition to providing education in the basic fields of study there were opened new fields preparing the students for the entrance into the labour market. The changes that have taken place in higher education and its environment created a special dimension of international mobility of students (Dybaś, Dziemianowicz-Bąk, Krawczyk-Radwan, Walczak, 2012).

If the only reference point taken for the evaluation of the higher education massification in Poland is the prism of statistical data on Polish universities, then it should be necessary to confirm the thesis that this process has already reached the highest point of growth and for several years has been characterized by a period of stagnation. This trend is noticeable both in terms of the number of higher education institutions, and the higher level enrolment 
rate. Taking the first years of transformation for the analysis, it can be assumed that in the academic year 1990/1991 universities educated a little more than 400 thous. persons (Ludwikowska, 2013). In the academic year 2017/2018 the number of students amounted to 1,291 thousand people. A record year in terms of the number of students was 2005, when the premises of Polish universities offered a place of study for nearly 1,940 thous. people. The increase in the number of students was very large. Only in the first five years of transformation the number of students doubled from 403 thous. to about 795 thous. people. Two years later, in 1997, the number of people studying at Polish universities exceeded one million persons. Each following year noted an increase in the number of students ranging from one hundred thousand to two hundred thousand people.

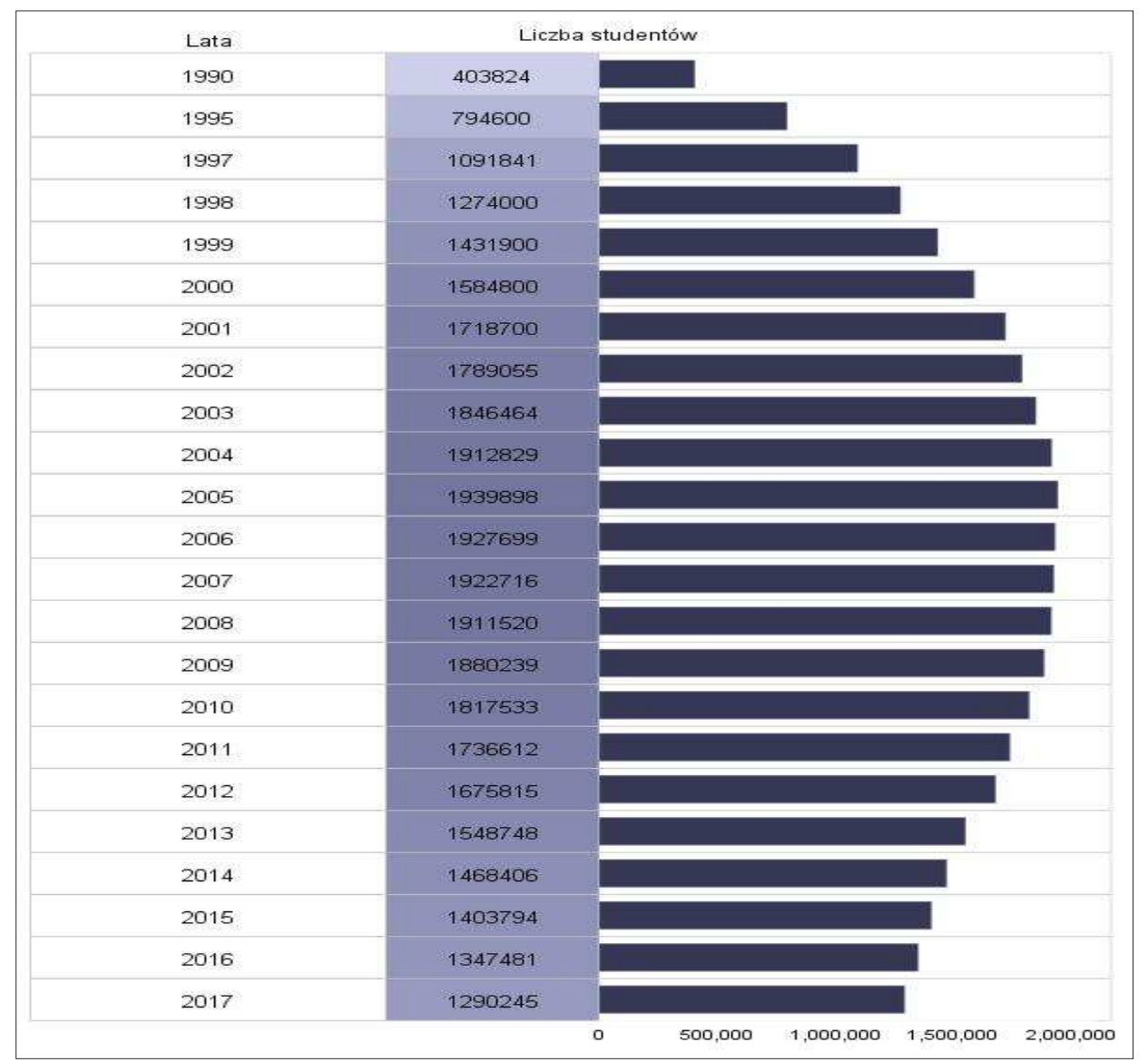

Chart 1. Number of students in years 1990-2017

Source: own calculations based on data from BDL GUS.

The dynamics of change can be clearly seen on the chart 2 , which takes as one hundred percent the number of students in 1990. 


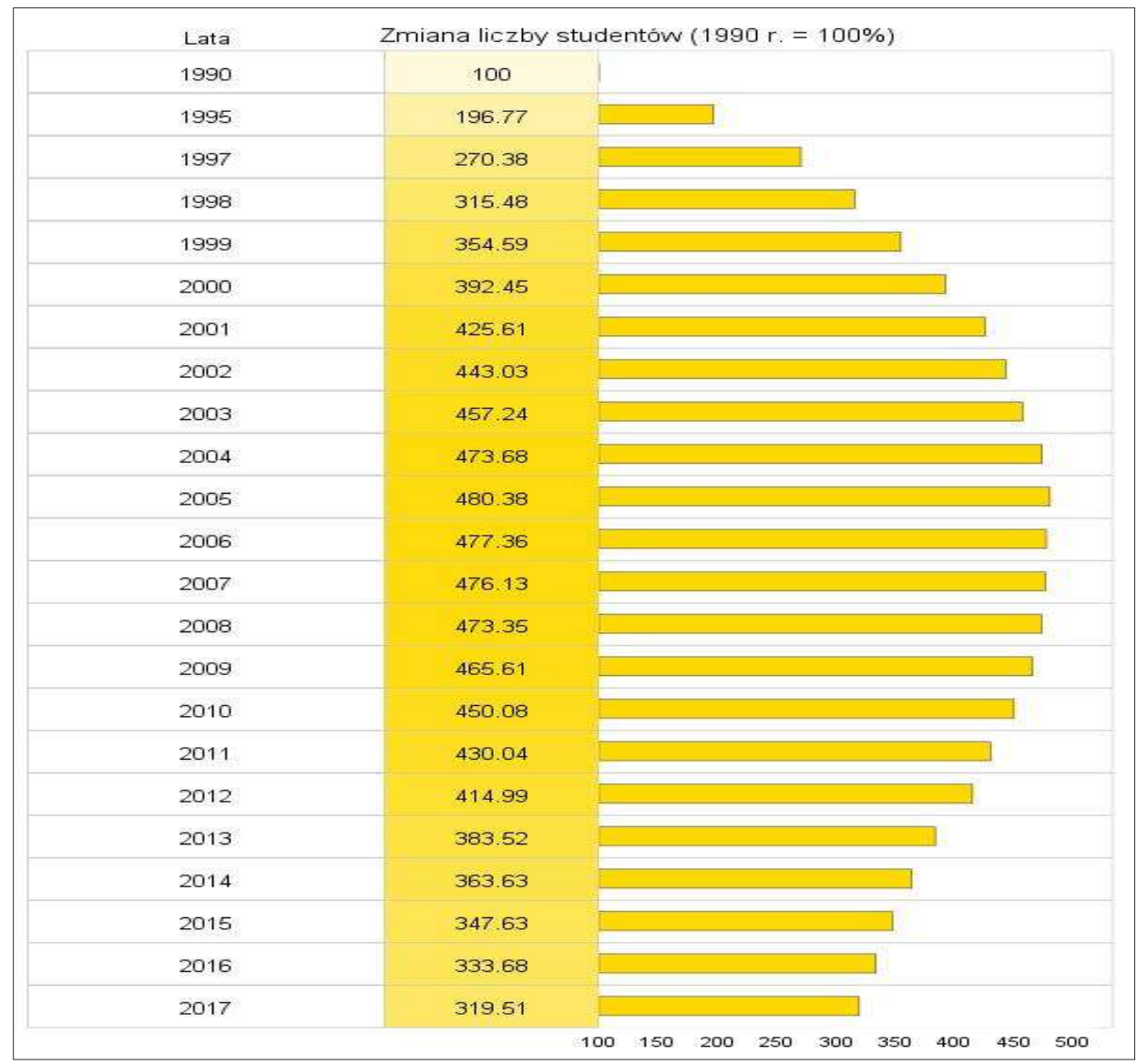

Chart 2. Dynamics of changes in the number of students in the years 1990-2017

Source: own calculations based on data from BDL GUS.

As can be observed, since 2001 the number of students has risen four times compared to 1990 . Since 2011 we have noted a continuous and significant fall in the number of students. This was due, on the one hand, to the demographic low, which negatively affected the number of students, and to the saturation of the market in persons who complemented their education mainly through part-time studies.

This was related to the increased demand observed in the nineties of the twentieth century for higher education and a limited offer (number of places for students) of full-time (daytime) studies at public universities. The answer to this process was a significant increase in the number of persons who took part-time studies in public universities or in non-public higher education institutions. 


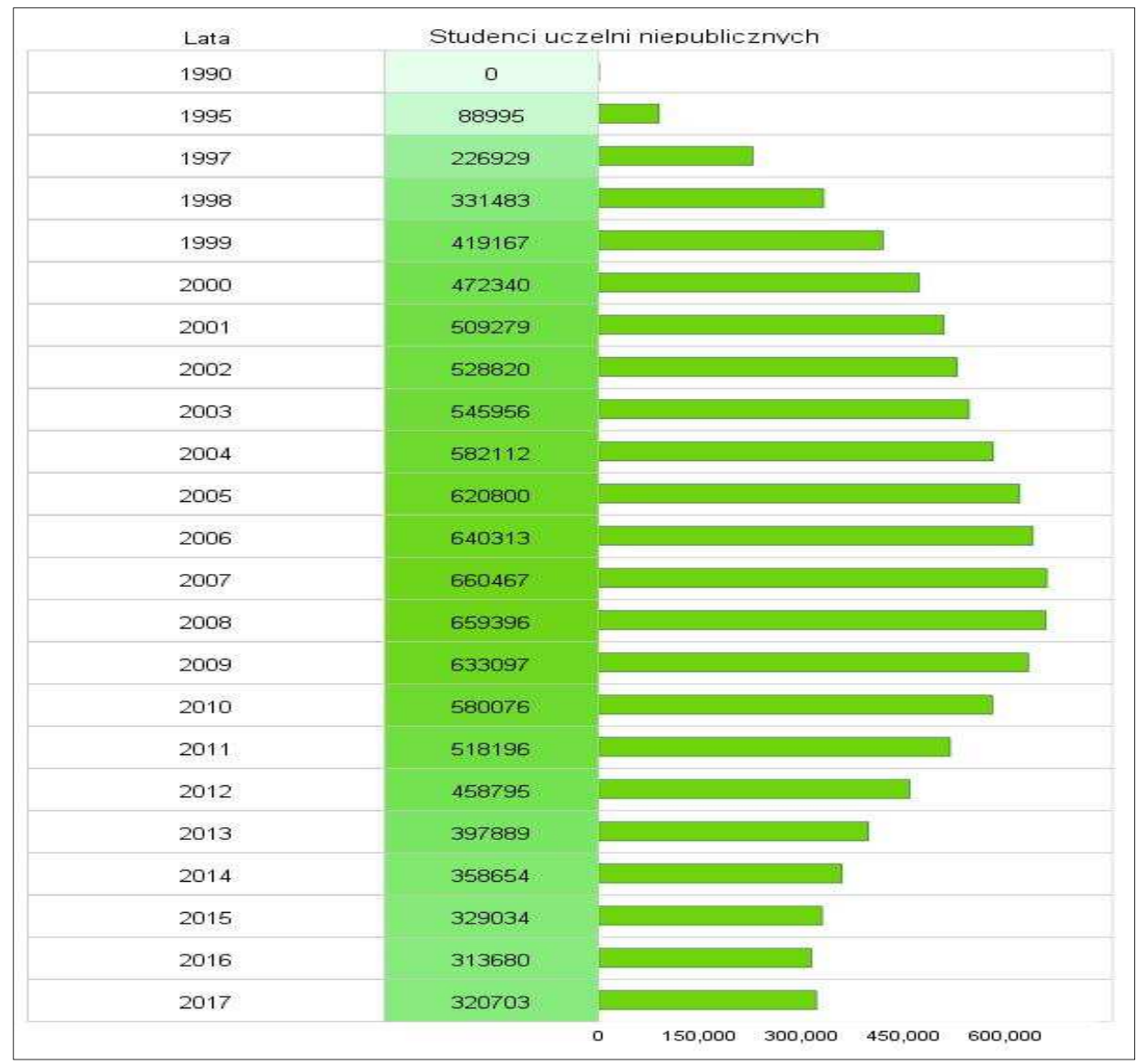

Chart 3. Number of students of non-public higher education institutions in years 1990-2017

Source: own calculations based on data from BDL GUS.

The number of students of non-public higher education institutions noted a dynamic growth. In 1990, there was no student at a non-public university as the first such a school was founded in August 1991. In 1995, the number of students of non-public universities was close to ninety thousand, and two years later it was already more than one hundred and thirty thousand bigger. At its peak - in 2006 the number of students of private universities amounted to 660 thous. people. Since 2010 we have observed a fairly rapid and continuous decline in the number of people choosing university studies in those higher education institutions. The current number of students in non-public higher education institutions is similar to the level in 1998.

In the years 1990-2017 the number of universities increased from 162 to 390. It should be noted that at the peak of the education boom the number of higher education institutions was between $460-2012$. 


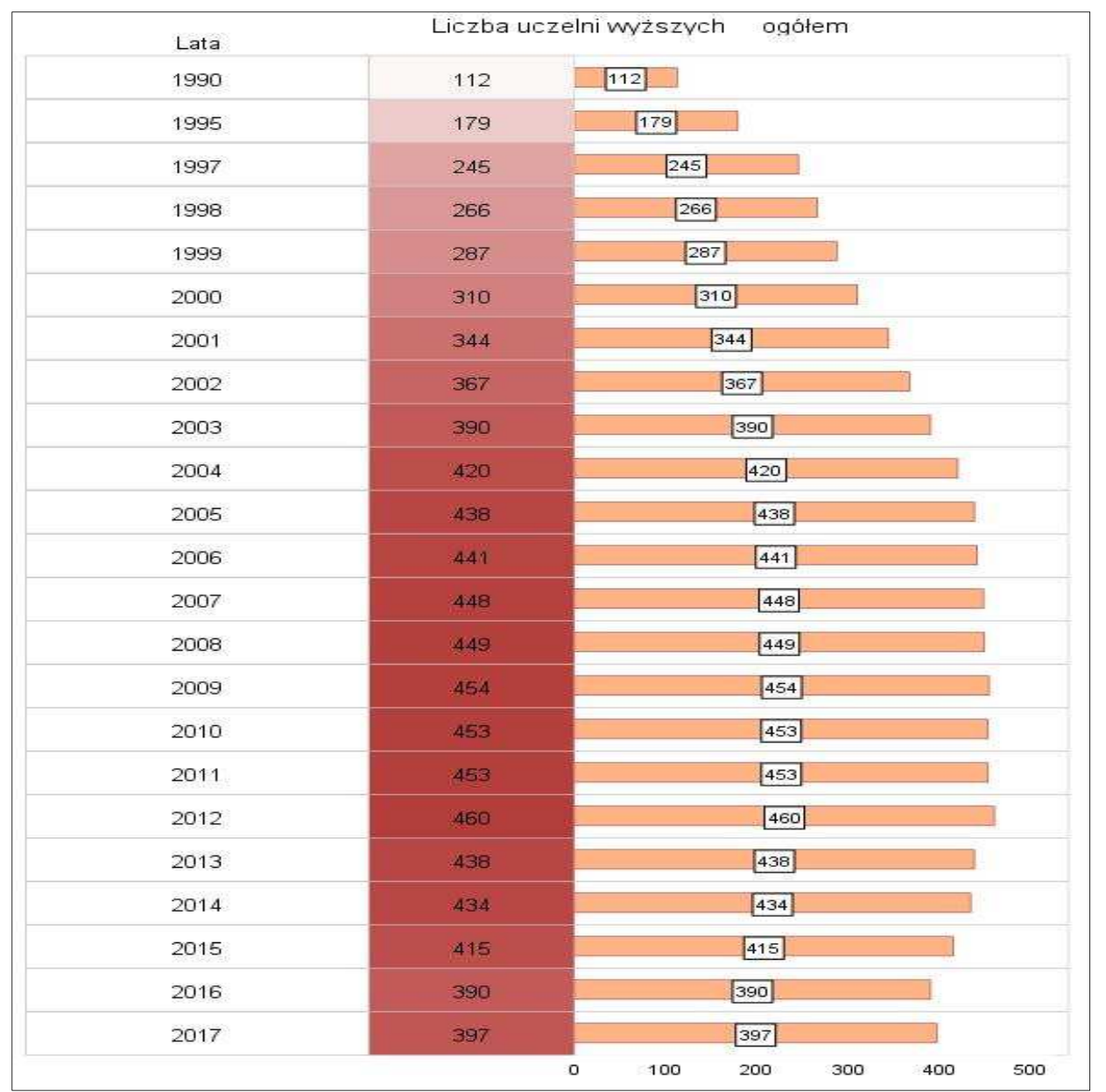

Chart 4. Number of higher education institutions in years 1990-2017

Source: own calculations based on data from BDL GUS.

The dynamics of changes have been presented in the chart 5 , which takes as a hundred percent the number of universities in 1990. In 2012, the number of universities hit the record high and exceeded by almost four hundred percent the value for the base year -1990 .

Polish society began to attribute great importance to education. This is shown by opinion polls, according to which the social assessment finds formal education an important determinant of successful career - one in three respondents $(32 \%)$ considers it as one of the factors contributing to the success in this sphere of life (Does Education matter?, 2013). The attractiveness of higher education is also reflected in other opinion polls, in which potential educational aspirations of parents related to their children. The vast majority of the respondents would like their sons and daughters to graduate with at least a diploma in engineering, bachelor's or master's degree (84\% -85\%) (Is education worth the investment?, 2017). Assigning high value to education is also confirmed by the enrolment ratio, which 
is a measure of popularity of education. The growth in the number of students and the number of universities was also accompanied by a significant increase in the gross enrolment ratio in higher education in Poland ${ }^{2}$. In the last several years, the enrolment rates in higher education were more than quadrupled. The value of gross enrolment ratio in higher education in 1990 was 12.9, while in 2017 it reached 53.8, it was also the climax, where the ratio was the highest.

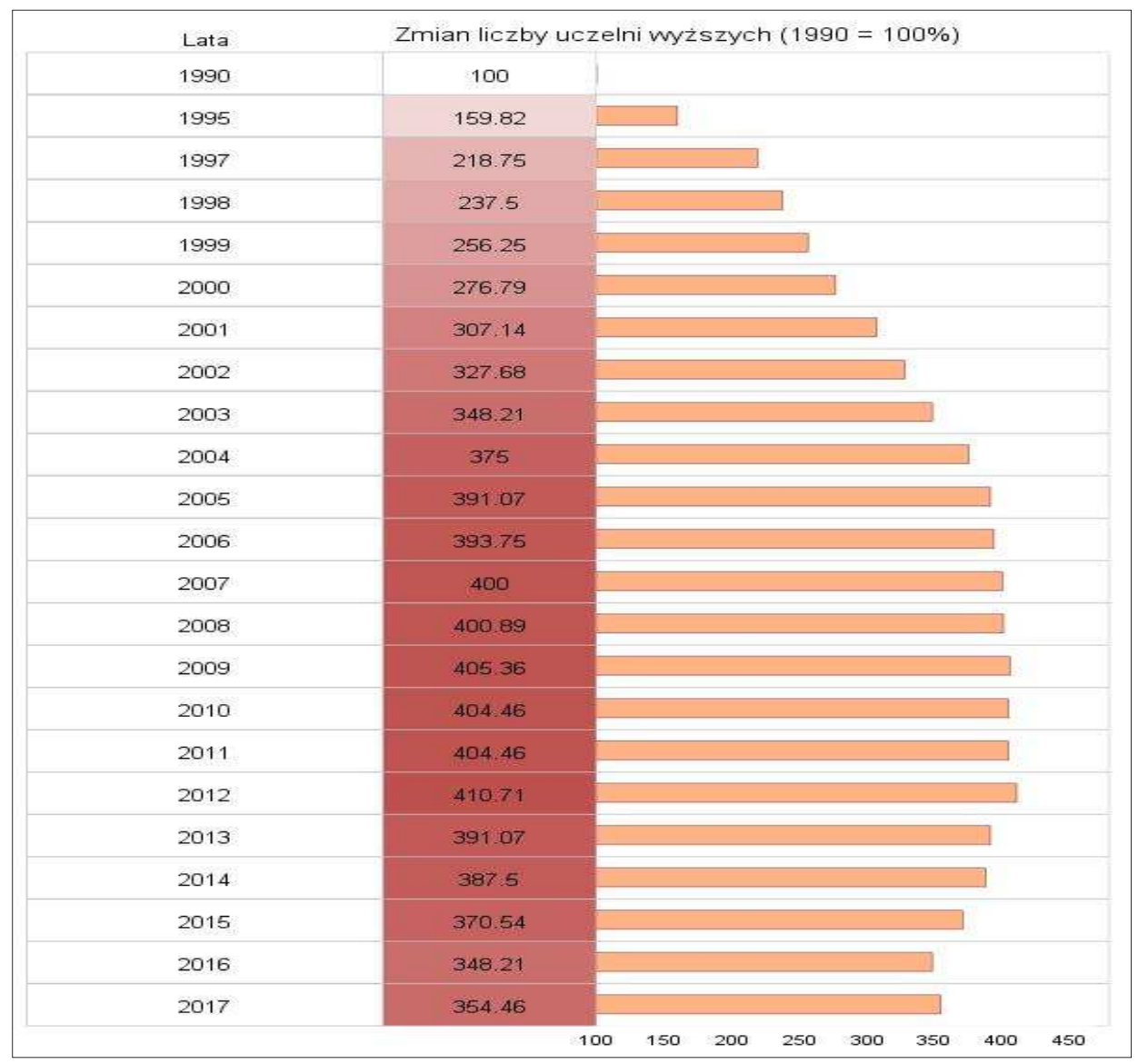

Chart 5. The dynamics of changes in the number of institutions of higher education in years 1990-2017

Source: own calculations based on data from BDL GUS.

${ }^{2}$ Gross enrolment ratio is the relation between the number of students (at the beginning of the school year) at a given level of education (regardless of age) to the population (as of 31 December) in the age group defined as corresponding to this level of education - in the case of higher education the nominal age of education is $19-24$ years. 


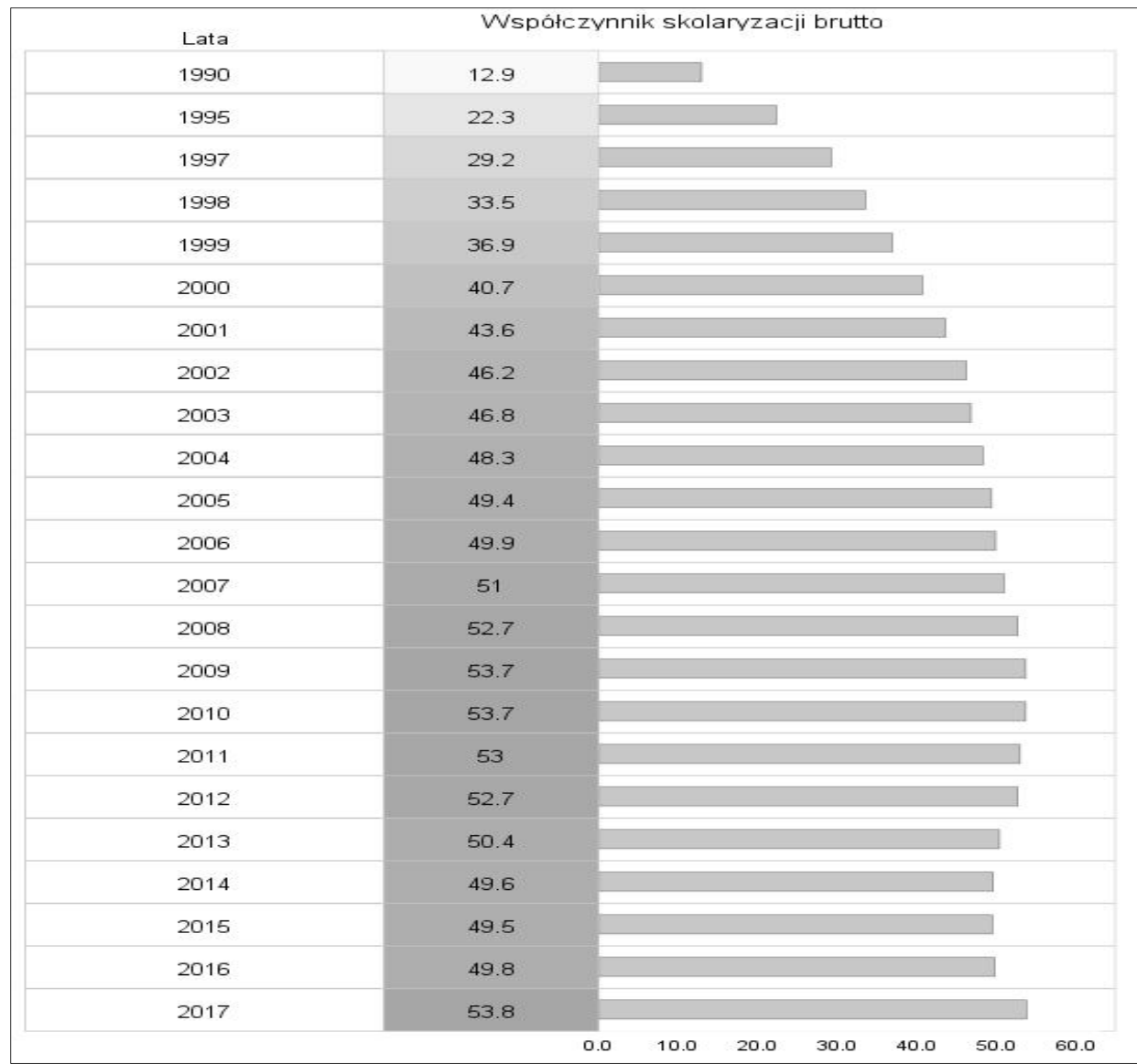

Chart 6. Gross enrolment ratio in years 1990-2017

Source: own calculations based on data from BDL GUS.

The increase in the number of students and universities was also connected with the increase in the number of people undertaking doctoral studies which, according to the Bologna Process principles, have become the next level of higher education (third-cycle studies), representing the continuation of studies after the Master's degree (second cycle). At the beginning of systemic transformation in the academic year 1990/1991a total of 2,695 persons followed doctoral studies conducted by universities, research institutes, scientific institutions of the Polish Academy of Sciences and the Centre for Postgraduate Medical Education. More than a quarter of a century later, in the academic year 2017/2018 the participants of doctoral studies totalled 43,181 persons, which means more than a fifteenfold increase compared to 1990 . 


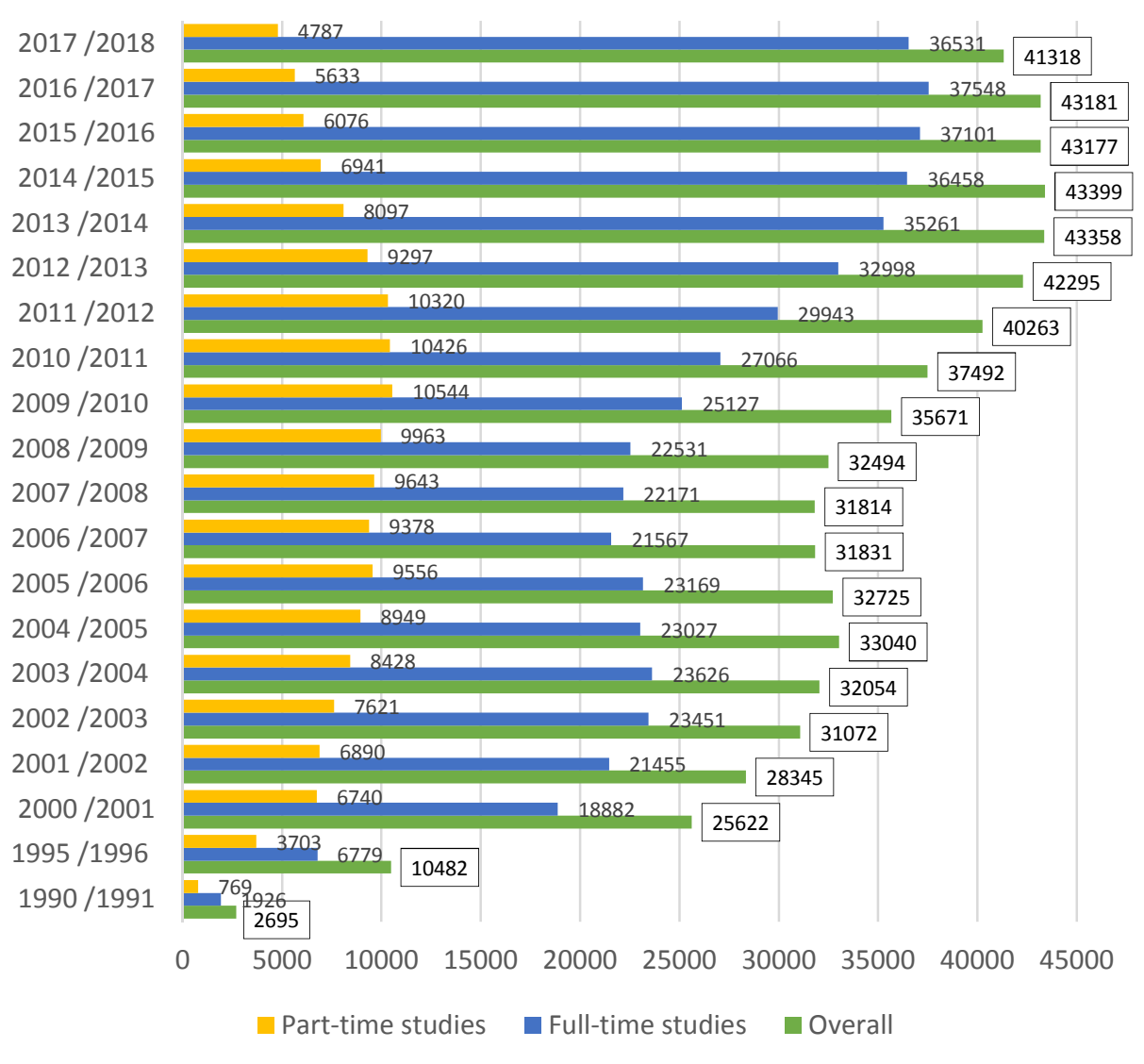

Chart 7. PhD students in the years 1990-2017

Source: own calculations based on the research Universities and their finances in 2017 (GUS, Warszawa 2018).

The process of massification of higher education varies spatially. The largest concentrations of universities and students are in the largest Polish cities. The most significant centre is Warsaw, which is definitely a cut above Krakow, Poznan and Wroclaw. It should be emphasized that in each province and its capital there is at least one university. Fig. 1 shows the spatial distribution of universities. 
Studenci:
Students:

w uczelniach macierzystych

in higher education institution

w filiach i zamiejscowych podstawowych jednostkach organizacyjnych

in branch campuses of a higher education institutions

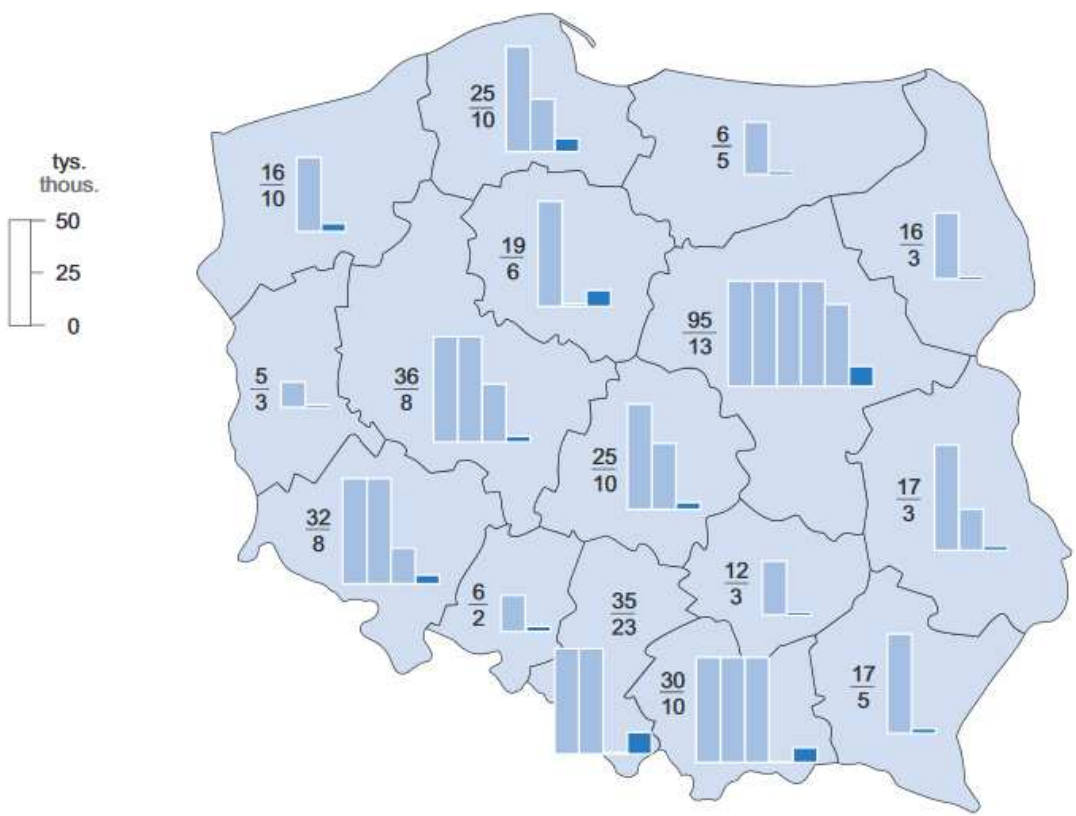

a Bez szkół resortów obrony narodowej oraz spraw wewnętrznych i administracji; w podziale według województw zamiejscowe jednostki organizacyjne zostaly wykazane w miejscu siedziby tych jednostek, z wyjątkiem zamiejscowych jednostek organizacyjnych działających za granicą, które zostaly wykazane w miejscu siedziby uczelni macierzystej.

Without educational institutions of the Ministry of National Defence and Ministry of Interior and Administration; in the breakdown by provinces the field organizational units have been presented at the seat of these units, with the exception of the field organizational units operating abroad, which have been presented at the seat of the home university.

Fig. 1. Students by provinces in the academic year 2017/2018

Source: Polish Statistical Yearbook 2018 (GUS, Warszawa 2018).

A very important consequence of the process of massification of higher education was a significant increase in the level of education of the Polish population. In light of the data of the National Population and Housing Census of 1988 the percentage of people with higher education was 6.9 per cent. According to Research Labour Force Survey (LFS) of the Central Statistical Office, the percentage of the population aged 15 and older with tertiary education in 2017 was 23.7 percent. 


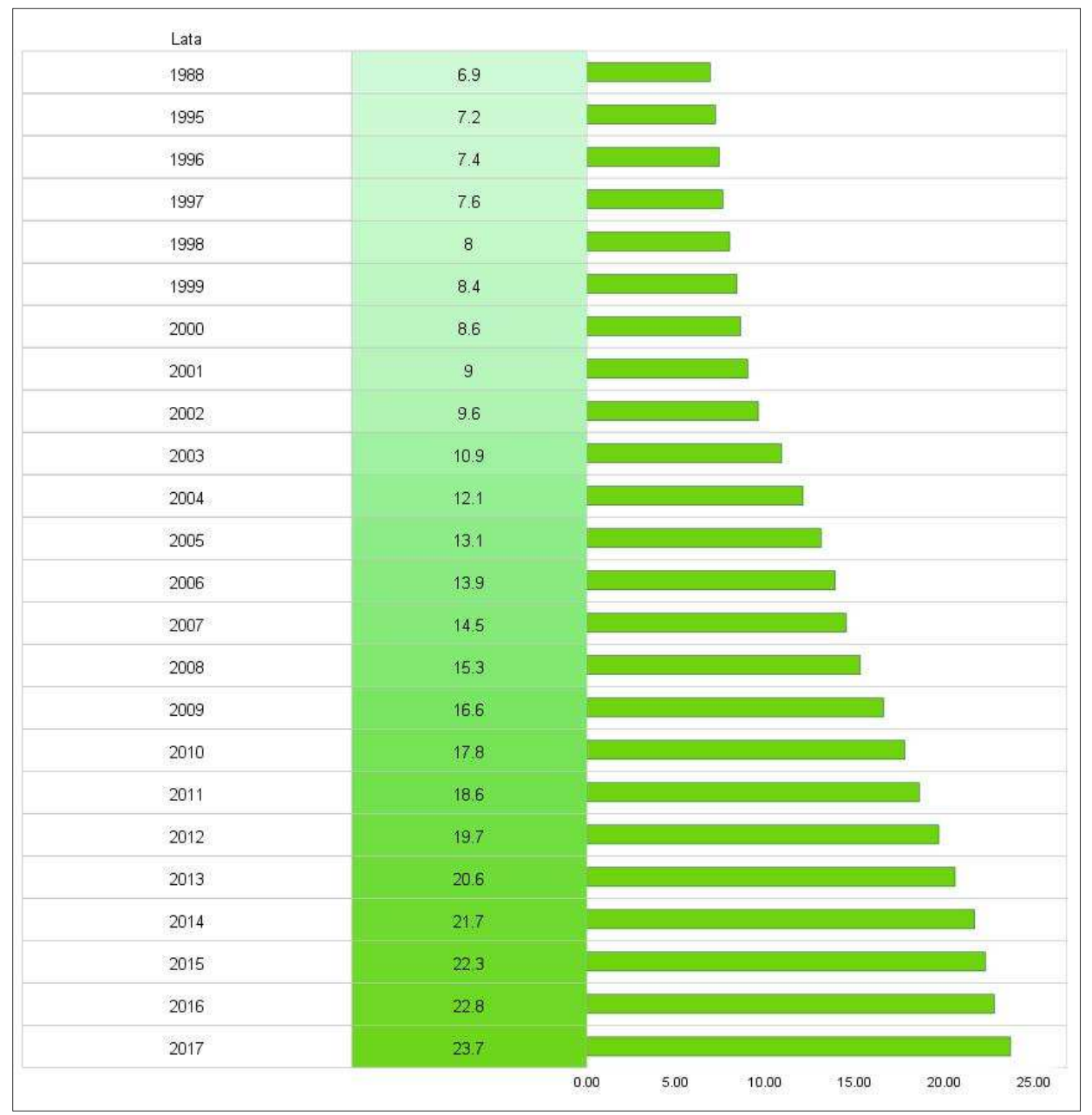

Chart 8. Percentage of persons with tertiary education in 2017

Source: own calculations based on data from BDL GUS.

\section{SUMMARY}

Changes in higher education and changes related to its popularisation were one of the clearest indicators of modernization of the Polish society of the late twentieth and early twenty-first century. The process of massification of higher education meant that nearly one quarter of Poles aged over 15 holds a higher education diploma. Over the last three years there has been noted, therefore, a nearly fourfold increase in the percentage of people with tertiary education. It should be noted that massification of higher education was accompanied by a new process of establishing of non-public higher education institutions. The increase in the student population is also to a large extent the result of the development of non-public education. In the years 1949-1989, Polish higher education system subjected 
to a strong state control saw no significant, systemic transformations (Dybaś, Dziemianowicz-Bąk, Krawczyk-Radwan, Walczak, 2012). The reforms introduced after 1989 and the integration with the European Union resulted in the autonomy of the universities and a significant marketisation of higher education. Universities, and mostly private educational institutions, have become companies providing educational services. The rapid growth of interest in higher education translated into a quantitative increase in the number of students and universities. It also led to a lower prestige of higher education and a shift from the elitist nature of universities and studies.

Overeducation of the young generation is a visible phenomenon in Poland. In the conditions of overeducation of the society, the value of higher education is lowered. The main indicator of this phenomenon is high unemployment among university graduates and work below qualifications. Richard Freeman's observations about American society have also been seen in Poland since the beginning of the 21st century. In the conditions of overeducation, the following actions take place: young people change their choices from humanities to technical ones, more often young people graduate from bachelor's studies than master's studies, and competition in access to the best universities and prestigious positions begins (Freeman, 1976). The massification of higher education meant that the situation of people who completed university studies is the same as the situation of people with secondary education. Often, higher education acquired by students was not adequate to the demand for specific professions, dynamically changing Polish economy again and again (Rószkiewicz, 2009). It should be noted, however, that the benefits of higher education have an impact on the fact that people with higher education are more flexible on the labor market. They have the ability to be more mobile and easier to retrain than those with secondary education.

\section{REFERENCES}

Beck, U. (2002). Risk society. On the way to a different modernity. Warszawa: Wydawnictwo Naukowe Scholar.

Ciechanowska, D. (2012). Thorough learning as a result of university studying [In:] Ciechanowska, D., ed., Determinants of academic learning outcomes. Szczecin: „Pedagogium” Wydawnictwo OR TWP.

Denek, K. (1998). For a new shape of education. Torun: Wydawnictwo Akapit.

Does Education matter? CBOS Survey Report, BS/96/2013, Warszawa, July 2013.

Freeman, R.B. (1976). The Overeducated American. New York.

Gudowski, J. (2010). Selected issues of socio-economic transformation [In:] Bąkiewicz, A., Żuławska, U., ed., Development in a globalizing world. Warszawa: PWE.

Is education worth the investment? CBOS Survey Report, No 62/2017, Warszawa, May 2017.

Karczmarczuk, K. (2009). Modernisation of higher education in Poland. The prospect theory of reflexive modernization, "Przeglad Socjologiczny", Vol. 58, from. 3.

Ludwikowska, K. (2013). Higher education and the labor market - in search of consensus. "Szkoła-Zawód-Praca”, No. 5/6.

Dybaś, M., Dziemianowicz-Bąk, A., Krawczyk-Radwan, M., Walczak, D. (2012). Higher education [In:] Federowicz, M., Wojciuk, A., ed., Report on the state of education from 2011. Warszawa: Instytut Badań Edukacyjnych. 
Rószkiewicz, M. (2009). Higher education and the labor market [In:] Matysiak, A., ed., Polish higher education. Condition, conditions and perspectives. Warszawa.

Wasielewski, K. (2015). Functions of higher education for rural areas - selected issues from the perspective of a sociologist. "Studia Obszarów Wiejskich", Vol. 40. DOI: 10.7163/SOW.40.2.

DOI: $10.7862 /$ rz.2020.hss.18

The text was submitted to the editorial office: December 2019.

The text was accepted for publication: June 2020. 
